\title{
The clinicopathological significance of RUNX3 hypermethylation and mRNA expression in human breast cancer, a meta-analysis
}

This article was published in the following Dove Press journal:

OncoTargets and Therapy

26 August 2016

Number of times this article has been viewed

\author{
Xiao-yun Songl,* \\ Bo-yan $\mathrm{Li}^{2, *}$ \\ En-xiang Zhou ${ }^{3}$ \\ Feng-xia $\mathrm{Wu}^{4}$ \\ 'Department of Thoracic Surgery, \\ Beijing Chest Hospital, Capital \\ Medical University, Beijing, People's \\ Republic of China; ${ }^{2}$ Department \\ of Breast Surgery, Inner Mongolia \\ Forestry General Hospital, Inner \\ Mongolia, People's Republic of China; \\ ${ }^{3}$ Department of General Surgery, \\ the Second Xiangya Hospital of \\ Central South University, Changsha, \\ Hunan, People's Republic of China; \\ ${ }^{4}$ Department of Breast Surgery, \\ Beijing Luhe Hospital, Capital Medical \\ University, Beijing, People's Republic \\ of China \\ *These authors contributed equally \\ to this work
}

\begin{abstract}
Aberrant promoter methylation of $R U N X 3$ has been reported in several tumors including human breast cancer (BC). However, the association between $R U N X 3$ hypermethylation and incidence of $\mathrm{BC}$ remains elusive. In this study, a detailed literature search was performed in Medline and Google Scholar for related research publications. Analysis of pooled data were executed. Odds ratios with corresponding confidence intervals were determined and summarized, respectively. Finally, 13 studies were identified for the meta-analysis. Analysis of the pooled data showed that $R U N X 3$ hypermethylation was significantly higher in both ductal carcinoma in situ and invasive ductal carcinoma (IDC) than in normal breast tissues. In addition, RUNX3 methylation was significantly higher in IDC than in benign tumor. However, $R U N X 3$ methylation was not significantly higher in IDC than in ductal carcinoma in situ. We also determined that $R U N X 3$ hypermethylation was significantly higher in ER positive $\mathrm{BC}$ than in ER negative $\mathrm{BC}$. In addition, high $R U N X 3 \mathrm{mRNA}$ expression was found to be correlated with better overall survival and relapse-free survival for all $\mathrm{BC}$ patients. Our results strongly support that $R U N X 3$ hypermethylation may play an important role in $\mathrm{BC}$ incidence. $R U N X 3$ methylation is a valuable early biomarker for the diagnosis of BC. Further large-scale studies will provide more insight into the role of RUNX3 hypermethylation in the carcinogenesis and clinical diagnosis of $\mathrm{BC}$ patients.
\end{abstract}

Keywords: breast cancer, estrogen receptor, $R U N X 3$, meta-analysis, methylation, odds ratio

\section{Introduction}

Breast carcinogenesis is a multi-step process that originates as flat epithelial atypia, progresses to atypical ductal hyperplasia, advances to ductal carcinoma in situ (DCIS), and culminates as invasive ductal carcinoma (IDC). ${ }^{1,2}$ Although early diagnostic tools, surgical approaches, and molecular targeted therapy have undergone considerable improvements, the incidence of breast cancer (BC) is still increasing, and the outcome of $\mathrm{BC}$ patients remains disappointing due to the high postoperative recurrence rate and metastasis., ${ }^{3,4}$ Thus, the identification of the molecular mechanisms of incidence and development of $\mathrm{BC}$ is still required and will help to provide better prognostic prediction and individualized treatments of patients with higher chances of $\mathrm{BC}$ recurrence.

$R U N X$ family genes consist of $R U N X 1, R U N X 2$, and $R U N X 3$. They are essential regulators of cell fate in the regulation of p53-dependent DNA damage response and/or tumorigenesis. ${ }^{5-7}$ RUNX3 interacts with CTNNB1/TCFs and prevents the transactivation by inhibiting CTNNB1/TCFs' DNA binding. ${ }^{8}$ Ito has observed that RUNX3 downregulates Wnt signaling by directly preventing $\beta$-catenin/TCFs in gastric and colon cancers. ${ }^{9}$ Therefore, RUNX3 via Wnt signaling pathway contributes to carcinogenesis as a tumor suppressor. The activation of the Wnt/CTNNB1 pathway was observed following
Correspondence: Feng-xia Wu Department of Breast Surgery, Beijing Luhe Hospital, Capital Medical University, 82 Xinhuananlu,

Tongzhou District, Beijing I0I I00,

People's Republic of China

Email fengxiawu@।26.com 
knockdown of PTEN in human breast cells. ${ }^{10}$ Furthermore, the downregulation of the secreted Wnt inhibitor Sfrp1 was reported in most invasive human breast carcinomas. ${ }^{11}$ RUNX3 was first reported as a tumor suppressor because of the causal link between the loss of RUNX3 and gastric carcinogenesis. ${ }^{12}$ Since then, RUNX3 has been observed as a suppressor that is inactivated in a wide variety of pre-invasive and invasive epithelial and mesenchymal neoplasms. ${ }^{13}$ RUNX3 protein regulates the growth-suppressive effects of TGF- $\beta$ by associating with SMAD, a downstream protein in the signaling pathway. ${ }^{14}$ Taken together, RUNX3 as a suppressor plays a critical role in the development of BC via TGF- $\beta^{15}$ and Wnt signaling pathway. ${ }^{16}$ Even if previous reports showed that inactivation of the $R U N X 3$ gene is mainly caused by its promoter hypermethylation in $\mathrm{BC}$, the positive rates of $R U N X 3$ hypermethylation in $\mathrm{BC}$ were extraordinarily diverse. In addition, it remains elusive whether or not $R U N X 3$ gene hypermethylation is correlated with the early stage of BC. In this study, we performed a metaanalysis to determine the effects of $R U N X 3$ hypermethylation on the incidence of BC. In addition, we evaluated RUNX3 mRNA as a prognostic marker in $\mathrm{BC}$ patients.

\section{Methods}

\section{Search strategy and methodological assessment}

We searched Embase, PubMed, and ISI web of knowledge to select studies from January 1, 1998 to October 2015 using the terms: "breast" and "cancer or tumor or neoplasm or carcinoma", "methylation", and "RUNX3". We also manually searched the reference lists of the retrieved reviews and articles for additional studies.

We used the following criteria for identification of studies: 1) $R U N X 3$ methylation examined in the primary $\mathrm{BC}$ tissues, 2) research showed the correlation between $R U N X 3$ methylation and $\mathrm{BC}$ incidence, 3 ) studies contained enough data to determine odds ratio (OR) and 95\% confidence interval (CI). The exclusion criteria were: 1) reviews, letters, case reports, editorials, conference abstracts, and expert opinions, 2) all articles regarding cell lines, in vitro/ex vivo studies, and human xenografts were also excluded.

We reviewed and evaluated data from the eligible studies. The following information was recorded for each study: year of publication, the first author's name, authors' country, number of cases, sample source, methylation detection method, clinicopathological parameters, methylation rate, and follow-up. Disagreements were resolved by discussion and consensus. Heterogeneity of studies was evaluated to determine whether the data could be used and analyzed for a meta-analysis. Data for study characteristics were summarized in a table format.
For the methodological evaluation of the studies, we read through each article independently, and assessed and scored them according to the Newcastle-Ottawa Quality Assessment Scale (NOQAS), for cohort and case-control studies. ${ }^{17}$ Studies are rated from one to nine stars in the NOQAS, with nine stars indicating a high-quality study. Any discrepancies or disagreements were discussed, and if consensus could not be achieved, a third reviewer resolved the issue. The Institutional Review Board of Beijing Chest Hospital does not require ethics approvals for these case studies.

\section{Prognostic value of RUNX3 mRNA expression in $B C$ patients}

An online database ${ }^{18}$ was used to determine the relevance of RUNX3 mRNA expression to prognosis of $\mathrm{BC}$ patients. We used the database that was established using gene expression data and survival information of 3,455 $\mathrm{BC}$ patients. RUNX3 gene was entered into the database (http://kmplot. com/analysis/index.php? $\mathrm{p}=$ service \&cancer=breast) to get Kaplan-Meier survival plots. The mRNA expression above or below the median separates the cases into high expression and low expression. Hazard ratio and 95\% CIs, as well as logrank $P$ were calculated.

\section{Statistical analysis}

Analysis was performed using the Review Manager 5.2 (Cochrane Collaboration, Oxford, UK) and STATA 12.0 (StataCorp LP, College Station, TX, USA). Heterogeneity among studies was determined with Cochran's Q test ${ }^{19}$ and the $I^{2}$ statistic. $^{20,21}$ If there was substantial heterogeneity ( $I^{2}$ values $\geq 50 \%$ ), a random-effects model was used to pool data and attempt to identify potential sources of heterogeneity based on subgroup analyses. When heterogeneity was not an issue $\left(I^{2}\right.$ values $\left.<50 \%\right)$, a fixed effect model was used to calculate parameters. The pooled frequency of RUNX3 hypermethylation and $95 \%$ CIs were estimated. $P$-values tailed less than 0.05 were considered statistically significant.

A method reported by Egger et al was used for assessment of publication bias. ${ }^{22}$ The analysis of meta-regression and publication bias was evaluated using STATA version 10.0. We also examined reasons for statistical heterogeneity using meta-regression, subgroup analysis, and sensitivity analysis.

\section{Results \\ Identification of relevant studies}

Six hundred and twenty-three articles were identified by the search method as described earlier. Six hundred and ten of those were excluded due to laboratory studies, non-original 
articles (review), or studies irrelevant to the current analysis. Finally, there were 13 studies included in final analysis, as shown in Figure 1.

\section{Study characteristics}

Thirteen reports published from 2005 to 2015 were selected and eligible for this meta-analysis. A total of $718 \mathrm{BC}$ patients from the People's Republic of China, Japan, Singapore, South Korea, and USA were enrolled. Basic study characteristics are shown in Table 1.

\section{The correlation of RUNX3}

\section{hypermethylation with carcinogenesis}

Comparison of RUNX3 hypermethylation in DCIS, IDC tissue, and normal breast tissue

We first assessed whether RUNX3 hypermethylation was significantly higher in DCIS than in normal breast tissues. The pooled OR from four studies including 134 DCIS and 103 normal breast tissue is shown in Figure $2 \mathrm{~A}(\mathrm{OR}=18.27$, $95 \%$ CI $=7.67-43.54, z$ score $=6.56, P<0.00001)$. There was no evidence of heterogeneity across the studies ( $P$ for heterogeneity $=0.13 ; P^{2}=47 \%$ ). $R U N X 3$ hypermethylation was also significantly higher in IDC than in normal breast tissues.
The pooled OR from five studies including 160 IDC and 123 normal breast tissue is shown in Figure 2B ( $O R=29.2,95 \%$ $\mathrm{CI}=12.52-68.14, z$ score $=7.81, P<0.00001)$. There was also no evidence of heterogeneity across the studies ( $P$-value for heterogeneity $=0.23 ; I^{2}=29 \%$ ).

\section{Comparison of RUNX3 hypermethylation in IDC vs benign tumor, IDC vs DCIS}

We then determined that RUNX3 methylation was significantly increased in IDC compared to a benign tumor, OR was 30.90 with $95 \% \mathrm{CI}=4.20-227.48, z$ score $=3.37, P=0.0008$, $P^{2}=66 \%, P=0.03$ (Figure 3A). However, $R U N X 3$ methylation was not significantly increased in IDC compared to DCIS, OR was 1.61 with $95 \% \mathrm{CI}=0.94-2.76, z$ score $=1.73, P=0.08$, $P^{2}=0 \%, P=0.8$ (Figure 3B).

\section{Association of RUNX3 hypermethylation with estrogen receptor status in $B C$ \\ Then, we determined whether or not $R U N X 3$ hypermethylation rate in $\mathrm{BC}$ was associated with ER status in $\mathrm{BC}$ patients. The pooled OR from four studies including 207 ER positive BC and 146 ER negative $\mathrm{BC}$ is shown in Figure $4(\mathrm{OR}=8.16,95 \%$ $\mathrm{CI}=4.53-14.71, z$ score $=6.99, P<0.00001, P=43 \%, P=0.15)$,}

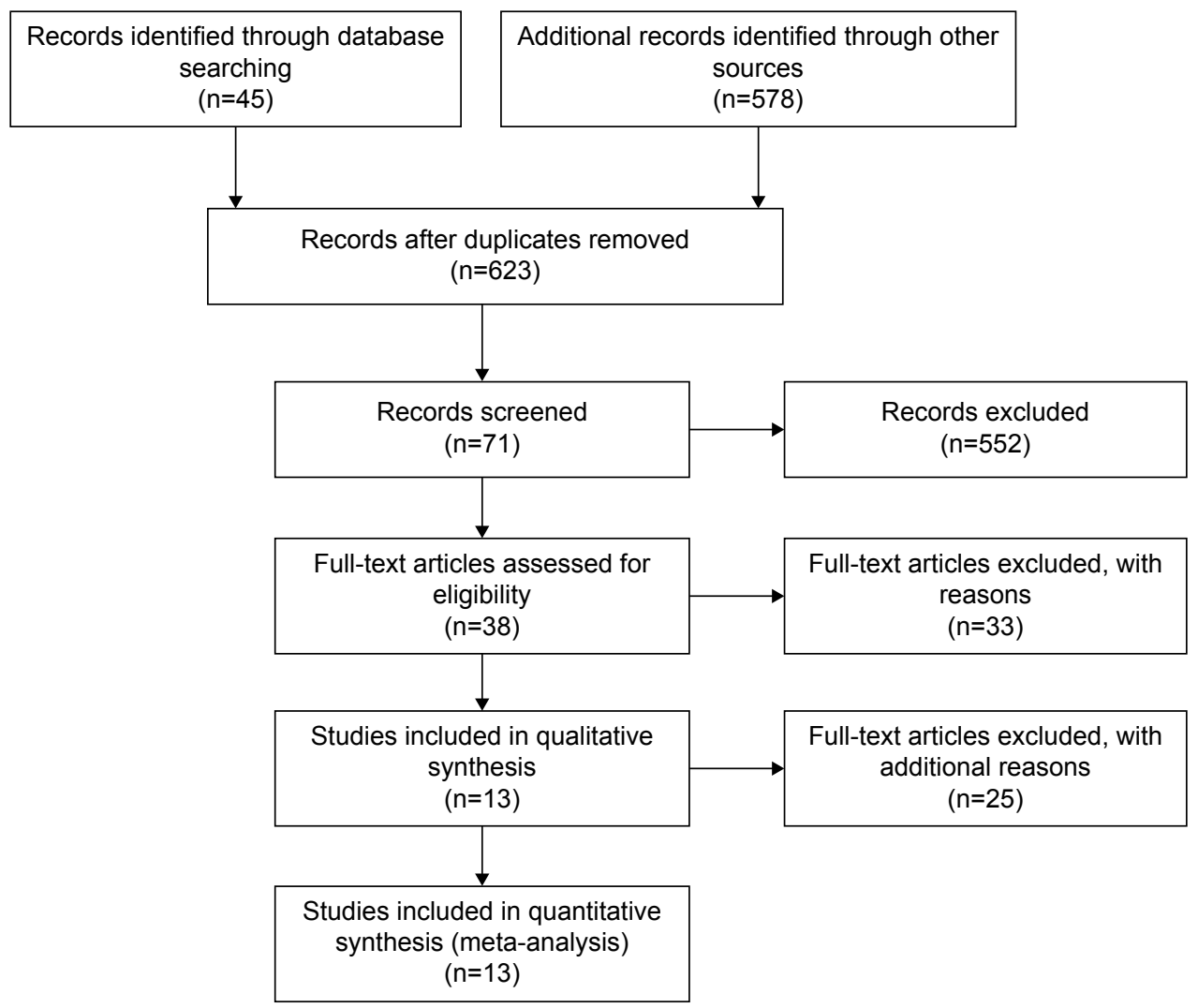

Figure I Schematic flow diagram for selection of included studies. 
Table I Main characteristics of included studies

\begin{tabular}{|c|c|c|c|c|}
\hline Study & Country & Patients (n) & Methods & Primary aims \\
\hline Yan et $\mathrm{al}^{54}$ & $\begin{array}{l}\text { People's Republic } \\
\text { of China }\end{array}$ & 113 & $\begin{array}{l}\text { Methylation specific } \\
\text { PCR (MSP) }\end{array}$ & $\begin{array}{l}\text { To investigate the relationship between } \\
\text { hypermethylation of } R U N X 3 \text { gene promoter and } \\
\text { ER in BC patients. }\end{array}$ \\
\hline Wang et $\mathrm{al}^{46}$ & $\begin{array}{l}\text { People's Republic } \\
\text { of China }\end{array}$ & 40 & MSP & $\begin{array}{l}\text { To investigate the methylation status of RUNX3 } \\
\text { promoter and RUNX3 expression in breast lesion } \\
\text { tissues. }\end{array}$ \\
\hline Li et $\mathrm{al}^{47}$ & $\begin{array}{l}\text { People's Republic } \\
\text { of China }\end{array}$ & 48 & MSP & $\begin{array}{l}\text { To investigate the methylation status of the RUNX3 } \\
\text { gene and protein expression in } B C \text { patients. }\end{array}$ \\
\hline Park et al ${ }^{48}$ & South Korea & 129 & Methylight & $\begin{array}{l}\text { To investigate the methylation status of I } 5 \text { tumor } \\
\text { suppressors in BC patients. }\end{array}$ \\
\hline Qiao et $\mathrm{a}^{49}$ & $\begin{array}{l}\text { People's Republic } \\
\text { of China }\end{array}$ & 60 & MSP & $\begin{array}{l}\text { To investigate the methylation status of the RUNX3 } \\
\text { gene in early diagnosis of } B C \text { patients. }\end{array}$ \\
\hline Park et $\mathrm{a}^{50}$ & South Korea & 35 & Methylight & $\begin{array}{l}\text { To assess the role of seven tumor suppressors in } \\
\text { BC patients. }\end{array}$ \\
\hline Subramaniam et $\mathrm{a}^{51}$ & Singapore & 40 & MSP, IHC & $\begin{array}{l}\text { To investigate the role of RUNX3 gene and protein } \\
\text { in the progression of } B C \text { patients. }\end{array}$ \\
\hline Du et $\mathrm{a}^{52}$ & $\begin{array}{l}\text { People's Republic } \\
\text { of China }\end{array}$ & 40 & MSP, IHC & $\begin{array}{l}\text { To investigate the role of } R U N X 3 \text { gene and protein } \\
\text { in the prediction of } B C \text {. }\end{array}$ \\
\hline Tian and Chen ${ }^{53}$ & $\begin{array}{l}\text { People's Republic } \\
\text { of China }\end{array}$ & 56 & MSP & $\begin{array}{l}\text { To determine the correlation of RUNX3 } \\
\text { methylation in } B C \text { and its pathologic features. }\end{array}$ \\
\hline Subramaniam et $\mathrm{al}^{31}$ & Singapore & 61 & MSP, IHC & $\begin{array}{l}\text { To investigate the role of RUNX3 gene and protein } \\
\text { in the progression of } B C \text { patients. }\end{array}$ \\
\hline Jiang et $\mathrm{a}^{41}$ & $\begin{array}{l}\text { People's Republic } \\
\text { of China }\end{array}$ & 15 & MSP, IHC & $\begin{array}{l}\text { To determine the correlation of RUNX3 } \\
\text { methylation and protein in } B C \text { and its pathologic } \\
\text { features. }\end{array}$ \\
\hline Lau et $\mathrm{al}^{39}$ & USA & 44 & MSP, RT-PCR & $\begin{array}{l}\text { To investigate the role of } R U N X 3 \text { gene and protein } \\
\text { in the progression of } B C \text { patients. }\end{array}$ \\
\hline Suzuki et al ${ }^{13}$ & Japan & 37 & MSP & $\begin{array}{l}\text { To investigate inactivation of TGF } \beta \text {-related genes } \\
D R M / G \text { remlin, RUNX3, and HPPI in human cancers. }\end{array}$ \\
\hline
\end{tabular}

Abbreviations: BC, breast cancer; IHC, immunohistochemistry; RT-PCR, reverse transcription polymerase chain reaction; ER, estrogen receptor.

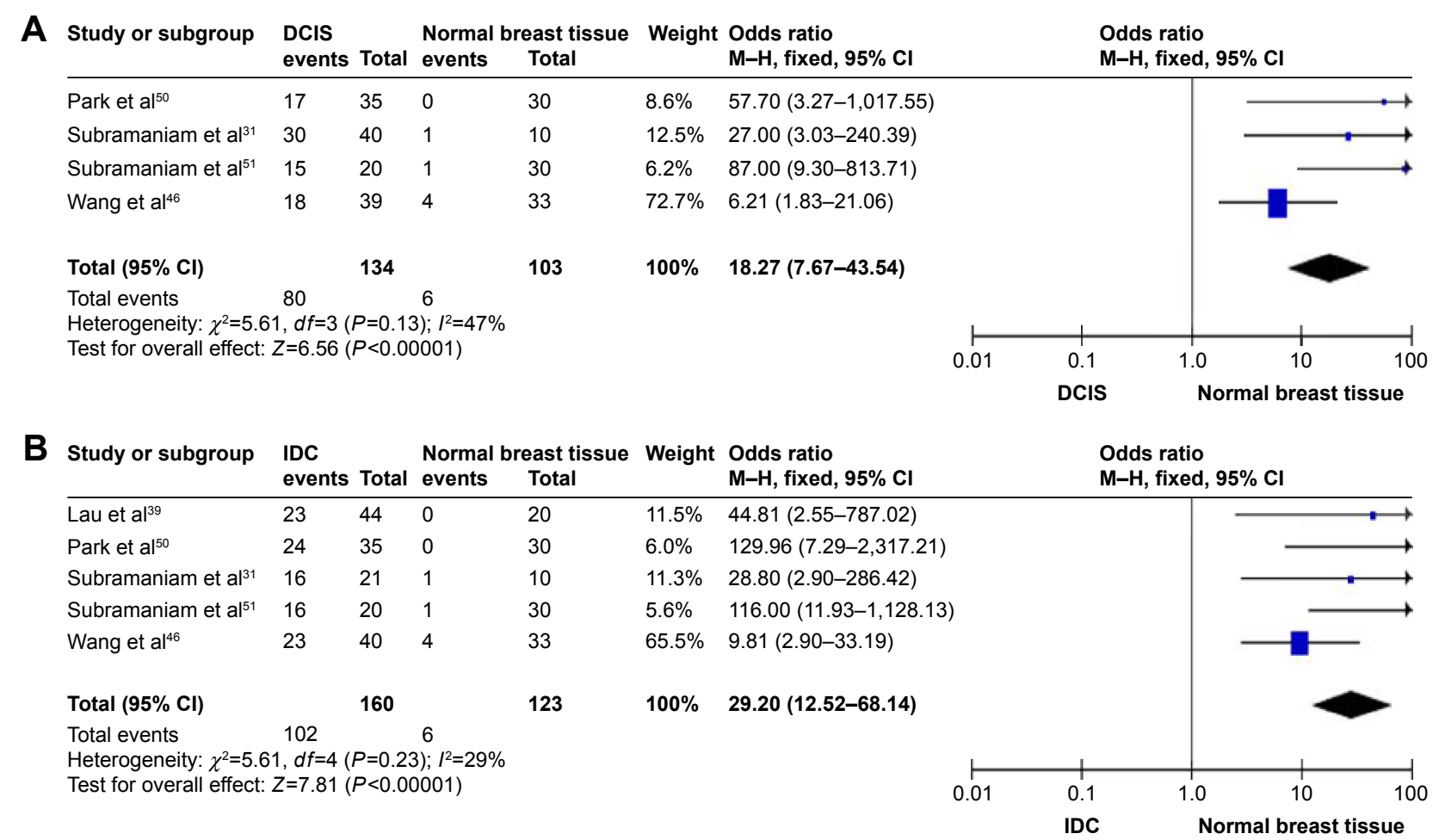

Figure 2 Comparison of RUNX3 hypermethylation in DCIS, IDC tissue and normal breast tissue.

Notes: (A) Forest plot for RUNX3 methylation in DCIS and normal breast tissue. (B) Forest plot for RUNX3 methylation in IDC and normal breast tissue.

Abbreviations: DCIS, ductal carcinoma in situ; IDC, invasive ductal carcinoma; Cl, confidence interval; $\mathrm{M}-\mathrm{H}$, Mantel-Haenszel; df, degrees of freedom. 


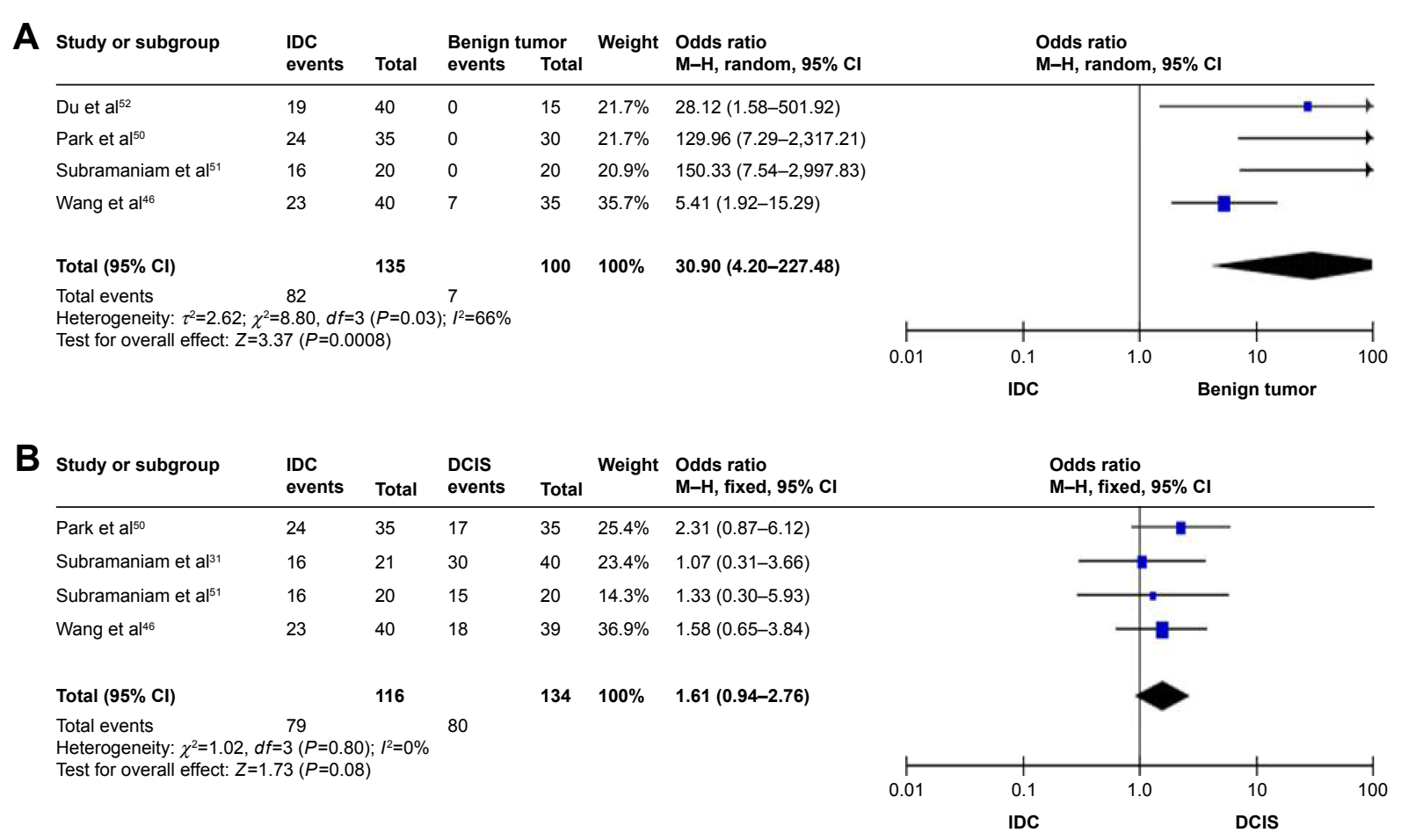

Figure 3 Comparison of RUNX3 hypermethylation in IDC vs benign tumor and IDC vs DCIS.

Notes: (A) Forest plot for RUNX3 methylation in IDC and benign tumor. (B) Forest plot for RUNX3 methylation in IDC and DCIS.

Abbreviations: DCIS, ductal carcinoma in situ; IDC, invasive ductal carcinoma; $\mathrm{Cl}$, confidence interval; $\mathrm{M}-\mathrm{H}$, Mantel-Haenszel; df, degrees of freedom.

indicating that RUNX3 hypermethylation was significantly higher in ER positive BC than in ER negative BC.

\section{Sensitivity analyses and publication bias}

A sensitivity analysis was conducted to assess the result stability. The pooled OR was not significantly changed, indicating the stability of our analyses. The funnel plots were largely symmetric (Figure 5A-E) suggesting there were no publication biases in the meta-analysis. We used the NOQAS for assessment of the quality of each study. Of 13 studies, three scored 8 points, six scored 7 points, and three scored 6 points. Therefore, the selected studies were of a relatively high quality (Table 2).

\section{Prognostic values of high RUNX3 mRNA expression in BC patients}

We finally assessed the clinical relevance of $R U N X 3$ in a patient survival analysis using an online database containing

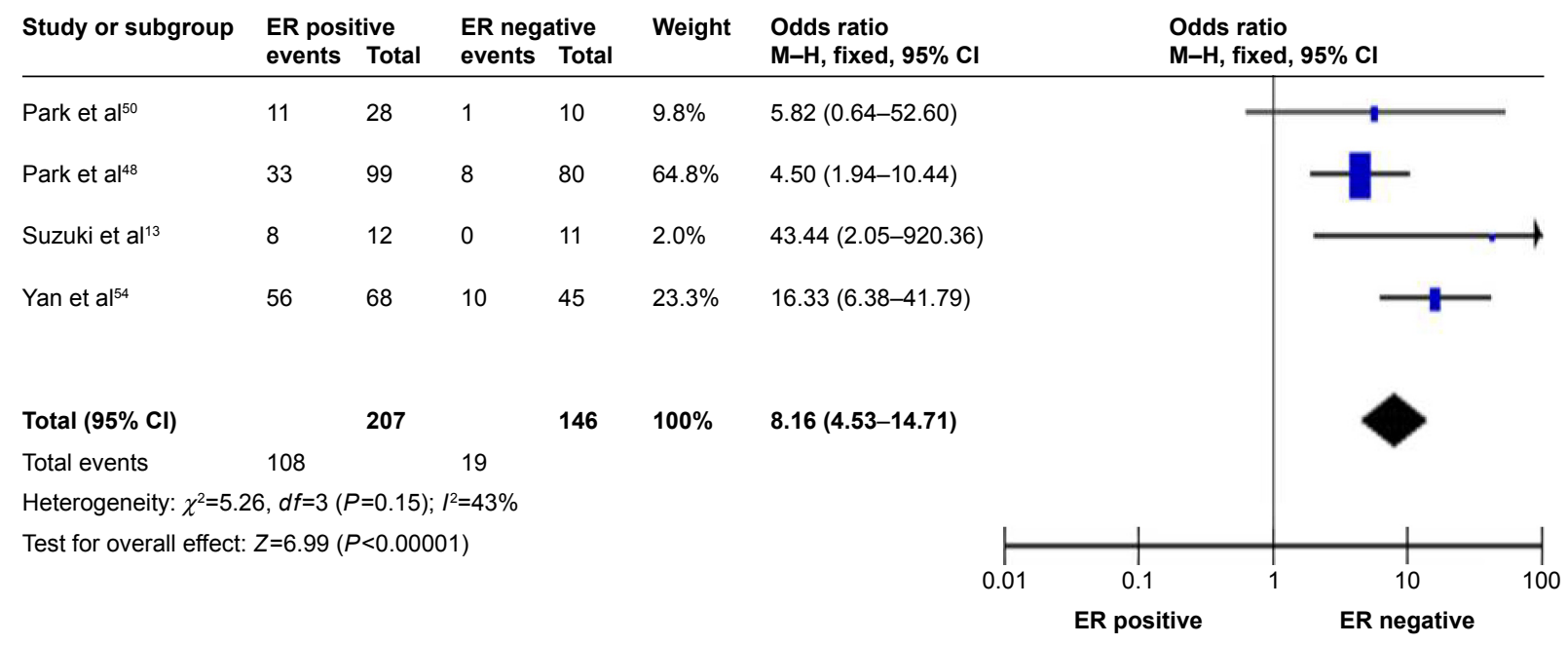

Figure 4 Forest plot for RUNX3 methylation in ER positive and negative of $\mathrm{BC}$.

Abbreviations: BC, breast cancer; $\mathrm{Cl}$, confidence interval; $\mathrm{M}-\mathrm{H}$, Mantel-Haenszel; df, degrees of freedom; ER, estrogen receptor. 

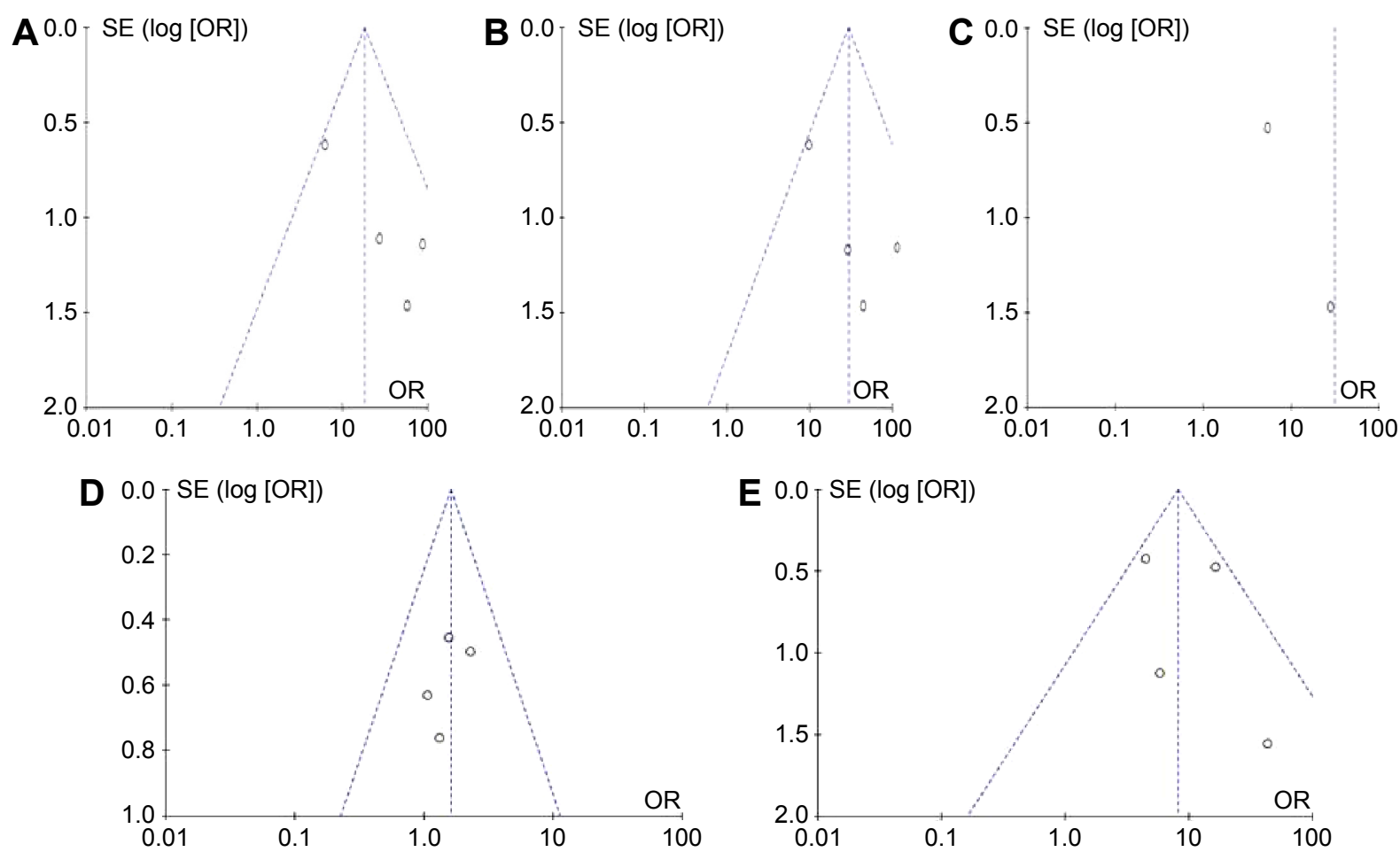

Figure 5 Funnel plot for publication bias.

Notes: (A) RUNX3 methylation in DCIS and normal breast tissue; (B) RUNX3 methylation in IDC and normal breast tissue; (C) RUNX3 methylation in IDC and benign tumor; (D) RUNX3 methylation in IDC and DCIS; (E) RUNX3 methylation in ER (+) and ER (-) breast cancer.

Abbreviations: DCIS, ductal carcinoma in situ; IDC, invasive ductal carcinoma; SE, standard error; OR, odds ratio; ER, estrogen receptor.

the expression of 22,277 genes and 20-year survival information of $3,455 \mathrm{BC}$ patients. ${ }^{18}$ High $R U N X 3$ mRNA expression was found to be correlated with better overall survival (OS) for all $\mathrm{BC}$ patients followed for 20 years (Figure 6A, hazard ratio 0.78, $P=0.037$ ). In addition, high RUNX3 mRNA expression was also found to be correlated with better relapse-free survival (RFS) for all $\mathrm{BC}$ patients followed for 20 years (Figure 6B, hazard ratio 0.8, $P=0.00013$ ).

\section{Discussion}

The RUNX3 transcription factor is a downstream effector of TGF- $\beta$ signaling pathway. TGF- $\beta$ is activated after binding to their respective cognate receptors, phosphorylate transducers named Smads. Smads 2 and Smads 3 are called R-Smads, which associate with a common Smad 4 (coSmad) and enter the nucleus. R-Smad/co-Smad complex binds to transcription factors and regulates the transcription of target genes. RUNX3 interacts with R-Smads,

Table 2 Quality assessment according to the Newcastle-Ottawa scale of the included studies

\begin{tabular}{|c|c|c|c|c|}
\hline Author & Selection & Comparability & Exposure & Total score \\
\hline Yan et $\mathrm{al}^{54}$ & 2 & 2 & 3 & 7 \\
\hline Wang et $\mathrm{a}^{46}$ & 2 & 2 & 3 & 7 \\
\hline Li et $\mathrm{al}^{47}$ & 2 & 2 & 3 & 7 \\
\hline Park et $\mathrm{al}^{48}$ & 3 & 2 & 3 & 8 \\
\hline Qiao et $\mathrm{a}^{49}$ & 2 & 1 & 3 & 6 \\
\hline Park et al ${ }^{50}$ & 2 & 2 & 3 & 7 \\
\hline Subramaniam et $\mathrm{a}^{51}$ & 3 & 2 & 3 & 8 \\
\hline Du et $\mathrm{al}^{52}$ & 2 & I & 3 & 6 \\
\hline Tian and $\mathrm{Chen}^{53}$ & 2 & 1 & 3 & 6 \\
\hline Subramaniam et $\mathrm{al}^{31}$ & 3 & 2 & 3 & 8 \\
\hline Jiang et $\mathrm{al}^{41}$ & 2 & 1 & 3 & 6 \\
\hline Lau et al ${ }^{39}$ & 2 & 2 & 3 & 7 \\
\hline Suzuki et $\mathrm{al}^{13}$ & 2 & 2 & 3 & 7 \\
\hline
\end{tabular}




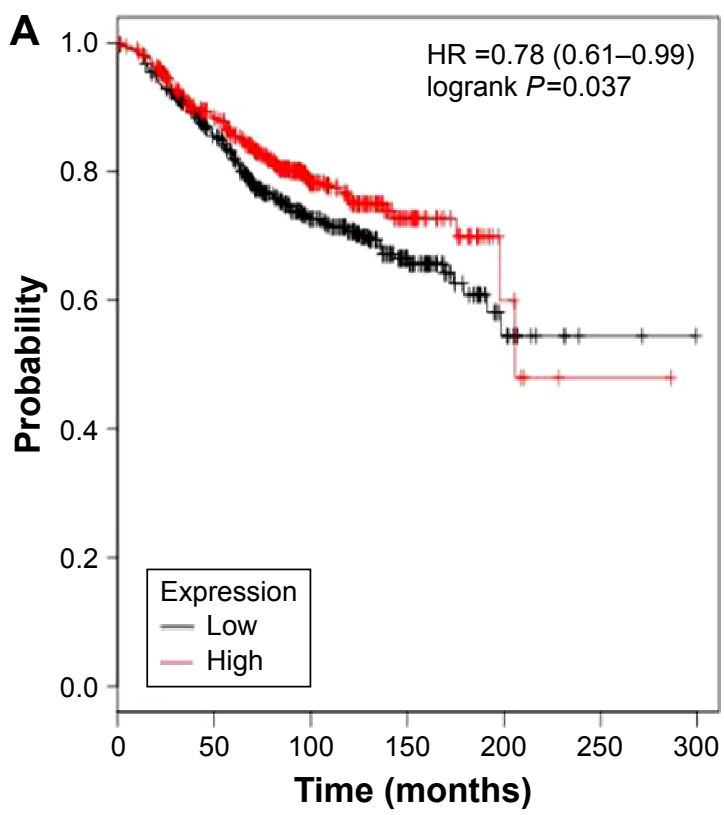

Number at risk

$\begin{array}{llllllll}\text { Low } & 558 & 440 & 241 & 82 & 15 & 2 & 0\end{array}$

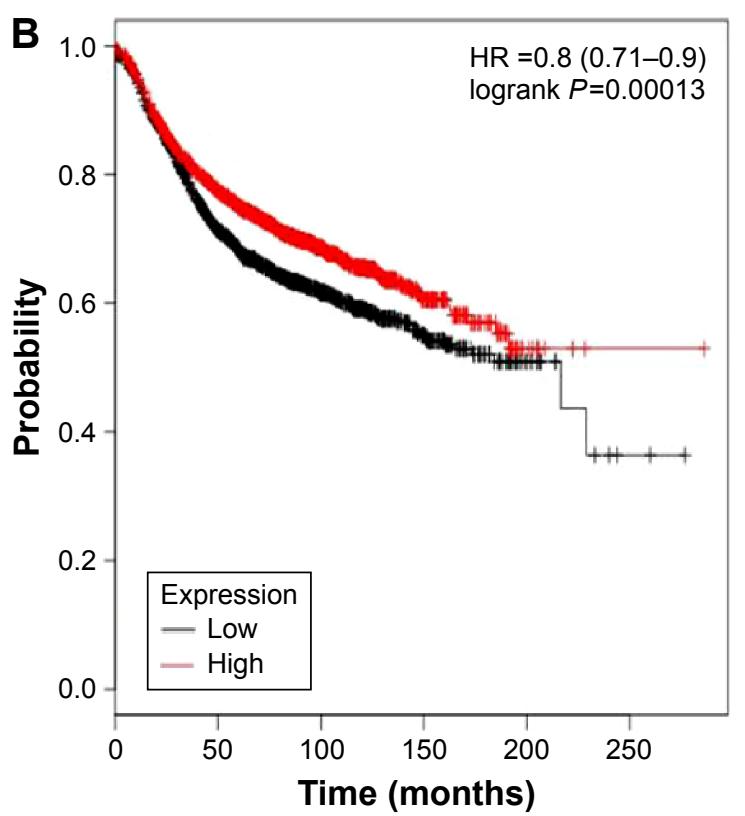

Number at risk

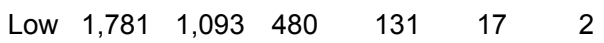

$\begin{array}{llllll}\text { High } & 1,773 & 1,222 & 590 & 110 & 10\end{array}$

Figure 6 The clinical relevance of RUNX3 was determined in a patient survival analysis using an online database containing the expression of 22,277 genes and 20-year survival information of 3,455 breast cancer (BC) patients.

Notes: (A) High RUNX3 mRNA expression was found to be correlated with better overall survival for all $B C$ patients followed for 20 years, hazard ratio (HR) 0.78 , $P=0.037$. (B) High RUNX3 mRNA expression was also found to be correlated with better relapse-free survival for all $B C$ patients followed for 20 years, HR $0.8, P=0.00013$.

co-Smads, and p300, a transcriptional co-activator, and fulfills its tumor suppressor activity via TGF- $\beta$ signaling pathway. ${ }^{14} R U N X 3$ hypermethylation plays an important role during normal development and tumorigenesis in several types of tumors including $\mathrm{BC} .{ }^{23-34}$ To date, there have been some studies describing the precise expression and methylation status of $R U N X 3$ in $\mathrm{BC}$; however, the roles of $R U N X 3$ hypermethylation in $\mathrm{BC}$ and its correlation with carcinogenesis have not been thoroughly investigated. Analysis of the pooled data showed that RUNX3 hypermethylation was significantly higher in both DCIS and IDC compared to normal breast tissues. In addition, RUNX3 methylation was significantly increased in IDC compared to a benign tumor. However, RUNX3 methylation was not significantly increased in IDC compared to DCIS. We also determined that $R U N X 3$ hypermethylation was significantly higher in ER positive $\mathrm{BC}$ than in ER negative $\mathrm{BC}$. The results from the current study indicated that the hypermethylation rate of $R U N X 3$ gene is an early event during $\mathrm{BC}$ carcinogenesis. Thus, $R U N X 3$ methylation is a valuable early detection biomarker for the diagnosis of BC.

Epigenetic alterations, particularly aberrant DNA methylation, one of the best-characterized epigenetic modifications, contribute to tumor initiation and progression..$^{35,36}$
RUNX3 has been reported to downregulate Wnt signaling by directly inhibiting CTNNB1/TCF4 in colon cancer and gastric cancer. ${ }^{9}$ Wnt signaling pathway is not only critical for the normal development of the mammary gland, but also for regulating cell proliferation and survival. RUNX3 inhibits the oncogenic Wnt signaling pathway via the formation of a complex with the TCF4-CTNNB1 complex and hampering it from binding to target genes such as $c-m y c$ and CCND1. ${ }^{24,37}$

RUNX3 also acts as a novel co-activator for p53 through regulating its DNA damage-induced phosphorylation at Ser-15 and mediates tumor suppression..$^{38}$ Numerous studies have supported that $R U N X 3$ is a suppressor and is inactivated in BC by protein mislocalization, ${ }^{31,39}$ reduced copy number, ${ }^{40}$ hemizygous deletion, and gene hypermethylation. ${ }^{41,42}$ Based on this meta-analysis, we may conclude that RUNX3 hypermethylation in $\mathrm{BC}$ tends to indicate higher incidence of $\mathrm{BC}$, its inactivation could contribute to tumor initiation and progression.

ER signaling plays an important role in the development of normal mammary gland through the regulation of genes involved in cell cycle and apoptosis. ${ }^{43}$ Abnormal ER signaling contributes to initiation and progression of $\mathrm{BC} .{ }^{44} \mathrm{~A}$ recent report has shown that RUNX3 inhibits ER signaling through 
suppressing the transcription activity of ER $\alpha$ and reducing ER $\alpha$-dependent cancer cell proliferation. ${ }^{45}$ In this metaanalysis, we determined that the pooled OR from four studies including $207 \mathrm{ER}$ positive $\mathrm{BC}$ and $146 \mathrm{ER}$ negative $\mathrm{BC}$, $\mathrm{OR}=8.16,95 \% \mathrm{CI}=4.53-14.71, z$ score $=6.99, P<0.00001$, $I^{2}=43 \%, P=0.15$, indicated that $R U N X 3$ hypermethylation was significantly higher in ER positive BC than in ER negative BC. Therefore, RUNX3 methylation could contribute to the development of BC by modulating ER signaling pathway.

RUNX3 mRNA expression might be due to the RUNX3 hypermethylation status in BC patients. Thus, we further assessed the prognostic value of high $R U N X 3$ mRNA expression in a patient survival analysis using an online database containing the expression of 22,277 genes and 20-year survival information of $3,455 \mathrm{BC}$ patients. ${ }^{18}$ High $R U N X 3$ mRNA expression was found to be correlated with better OS for all $\mathrm{BC}$ patients followed for 20 years, hazard ratio 0.78 , $P=0.037$. In addition, high $R U N X 3$ mRNA expression was also found to be correlated with better RFS for all $\mathrm{BC}$ patients followed for 20 years, hazard ratio $0.8, P=0.00013$.

\section{Conclusion}

This meta-analysis showed that $R U N X 3$ methylation is significantly increased in DCIS and IDC. The frequency of $R U N X 3$ methylation is associated with ER status in patients with BC. In addition, high RUNX3 mRNA expression was found to be correlated with better OS and RFS for all BC patients. Our results strongly support that $R U N X 3$ hypermethylation may play an important role in $\mathrm{BC}$ incidence. $R U N X 3$ methylation is a valuable early biomarker for the diagnosis of BC. Further large-scale studies will provide more insight into the role of RUNX3 in the carcinogenesis and clinical diagnosis of $\mathrm{BC}$ patients.

\section{Disclosure}

The authors have no financial involvement with any organization or entity with a financial interest in the subject matter or materials discussed in the paper. The authors report no conflicts of interest in this work.

\section{References}

1. O'Connell P, Pekkel V, Fuqua S, Osborne CK, Allred DC. Molecular genetic studies of early breast cancer evolution. Breast Cancer Res Treat. 1994; 32(1):5-12.

2. Hilton HN, Kantimm S, Graham JD, Clarke CL. Changed lineage composition is an early event in breast carcinogenesis. Histol Histopathol. 2013; 28(9):1197-1204.

3. Redig AJ, McAllister SS. Breast cancer as a systemic disease: a view of metastasis. J Intern Med. 2013;274(2):113-126.
4. Coleman RE, Gregory W, Marshall H, Wilson C, Holen I. The metastatic microenvironment of breast cancer: clinical implications. Breast. 2013; 22 Suppl 2:S50-S56.

5. Ozaki T, Nakagawara A, Nagase H. RUNX family participates in the regulation of p53-dependent DNA damage response. Int J Genomics. 2013;2013:271347.

6. Ito Y. RUNX genes in development and cancer: regulation of viral gene expression and the discovery of RUNX family genes. Adv Cancer Res. 2008;99:33-76.

7. Blyth K, Cameron ER, Neil JC. The RUNX genes: gain or loss of function in cancer. Nat Rev Cancer. 2005;5(5):376-387.

8. Ito K, Lim AC, Salto-Tellez M, et al. RUNX3 attenuates betacatenin/T cell factors in intestinal tumorigenesis. Cancer Cell. 2008; 14(3):226-237.

9. Ito K. RUNX3 in oncogenic and anti-oncogenic signaling in gastrointestinal cancers. J Cell Biochem. 2011;112:1243-1249.

10. Korkaya H, Paulson A, Charafe-Jauffret E, et al. Regulation of mammary stem/progenitor cells by PTEN/Akt/beta-catenin signaling. PLoS Biol. 2009;7(6):e1000121.

11. Roarty K, Rosen JM. Wnt and mammary stem cells: hormones cannot fly wingless. Curr Opin Pharmacol. 2010;10(6):643-649.

12. Li QL, Ito K, Sakakura C, et al. Causal relationship between the loss of RUNX3 expression and gastric cancer. Cell. 2002;109(1): 113-124.

13. Suzuki M, Shigematsu H, Shames DS, et al. DNA methylation-associated inactivation of TGFbeta-related genes DRM/Gremlin, RUNX3, and HPP1 in human cancers. Br J Cancer. 2005;93(9):1029-1037.

14. Ito Y, Miyazono K. RUNX transcription factors as key targets of TGFbeta superfamily signaling. Curr Opin Genet Dev. 2003;13(1):43-47.

15. Boone SD, Baumgartner KB, Baumgartner RN, et al. Associations between genetic variants in the TGF-beta signaling pathway and breast cancer risk among Hispanic and non-Hispanic white women. Breast Cancer Res Treat. 2013;141(2):287-297.

16. Bai J, Yong HM, Chen FF, et al. RUNX3 is a prognostic marker and potential therapeutic target in human breast cancer. $J$ Cancer Res Clin Oncol. 2013;139(11):1813-1823.

17. Wells GA, Shea B, O'Connell D, et al. The Newcastle-Ottawa Scale (NOS) for assessing the quality of nonrandomised studies in metaanalyses. Ottawa Health Research Institute; 2014. Available from: http:// www.ohri.ca/programs/clinical_epidemiology/oxford.asp. Accessed December 4, 2015.

18. Gyorffy B, Lanczky A, Eklund AC, et al. An online survival analysis tool to rapidly assess the effect of 22,277 genes on breast cancer prognosis using microarray data of 1,809 patients. Breast Cancer Res Treat. 2010; 123(3):725-731.

19. DerSimonian R, Laird N. Meta-analysis in clinical trials. Control Clin Trials. 1986;7(3):177-188.

20. Higgins JP, Thompson SG, Deeks JJ, Altman DG. Measuring inconsistency in meta-analyses. BMJ. 2003;327(7414):557-560.

21. DerSimonian R. Meta-analysis in the design and monitoring of clinical trials. Stat Med. 1996;15(12):1237-1248.

22. Egger M, Davey Smith G, Schneider M, Minder C. Bias in meta-analysis detected by a simple, graphical test. BMJ. 1997;315(7109):629-634.

23. Shiraha H, Nishina S, Yamamoto K. Loss of runt-related transcription factor 3 causes development and progression of hepatocellular carcinoma. J Cell Biochem. 2011;112(3):745-749.

24. Chuang LS, Ito Y. RUNX3 is multifunctional in carcinogenesis of multiple solid tumors. Oncogene. 2010;29(18):2605-2615.

25. Lee JH, Pyon JK, Kim DW, et al. Expression of RUNX3 in skin cancers. Clin Exp Dermatol. 2011;36(7):769-774.

26. Lee JM, Shin JO, Cho KW, et al. Runx3 is a crucial regulator of alveolar differentiation and lung tumorigenesis in mice. Differentiation. 2011; 81(4):261-268.

27. Lee YM. Control of RUNX3 by histone methyltransferases. $J$ Cell Biochem. 2011;112(2):394-400.

28. Levanon D, Brenner O, Otto F, Groner Y. Runx3 knockouts and stomach cancer. EMBO Rep. 2003;4(6):560-564. 
29. Lee YS, Lee JW, Jang JW, et al. Runx3 inactivation is a crucial early event in the development of lung adenocarcinoma. Cancer Cell. 2013; 24(5):603-616.

30. Araki K, Osaki M, Nagahama Y, et al. Expression of RUNX3 protein in human lung adenocarcinoma: implications for tumor progression and prognosis. Cancer Sci. 2005;96(4):227-231.

31. Subramaniam MM, Chan JY, Soong R, et al. RUNX3 inactivation by frequent promoter hypermethylation and protein mislocalization constitute an early event in breast cancer progression. Breast Cancer Res Treat. 2009;113(1):113-121.

32. Hwang KT, Han W, Bae JY, et al. Downregulation of the RUNX3 gene by promoter hypermethylation and hemizygous deletion in breast cancer. J Korean Med Sci. 2007;22 Suppl:S24-S31.

33. Mu WP, Wang J, Niu Q, Shi N, Lian HF. Clinical significance and association of RUNX3 hypermethylation frequency with colorectal cancer: a meta-analysis. Onco Targets Ther. 2014;7:1237-1245.

34. Yang Y, Ye Z, Zou Z, Xiao G, Luo G, Yang H. Clinicopathological significance of RUNX3 gene hypermethylation in hepatocellular carcinoma. Tumour Biol. 2014;35(10):10333-10340.

35. Delpu Y, Cordelier P, Cho WC, Torrisani J. DNA methylation and cancer diagnosis. Int J Mol Sci. 2013;14(7):15029-15058.

36. Ma X, Wang YW, Zhang MQ, Gazdar AF. DNA methylation data analysis and its application to cancer research. Epigenomics. 2013;5(3): 301-316.

37. Voon DC, Wang H, Koo JK, et al. Runx 3 protects gastric epithelial cells against epithelial-mesenchymal transition-induced cellular plasticity and tumorigenicity. Stem Cells. 2012;30(10):2088-2099.

38. Yamada C, Ozaki T, Ando K, et al. RUNX3 modulates DNA damagemediated phosphorylation of tumor suppressor p53 at Ser-15 and acts as a co-activator for p53. J Biol Chem. 2010;285(22):16693-16703.

39. Lau QC, Raja E, Salto-Tellez M, et al. RUNX3 is frequently inactivated by dual mechanisms of protein mislocalization and promoter hypermethylation in breast cancer. Cancer Res. 2006;66(13):6512-6520.

40. Chen W, Salto-Tellez M, Palanisamy N, et al. Targets of genome copy number reduction in primary breast cancers identified by integrative genomics. Genes Chromosomes Cancer. 2007;46(3):288-301.

41. Jiang Y, Tong D, Lou G, Zhang Y, Geng J. Expression of RUNX3 gene, methylation status and clinicopathological significance in breast cancer and breast cancer cell lines. Pathobiology. 2008;75(4):244-251.

42. Hwang KT, Han W, Bae JY, et al. Downregulation of the RUNX3 gene by promoter hypermethylation and hemizygous deletion in breast cancer. J Korean Med Sci. 2007;22 Suppl:S24-S31.
43. Katzenellenbogen BS, Katzenellenbogen JA. Estrogen receptor transcription and transactivation: estrogen receptor alpha and estrogen receptor beta: regulation by selective estrogen receptor modulators and importance in breast cancer. Breast Cancer Res. 2000;2(5):335-344.

44. Cheskis BJ, Greger JG, Nagpal S, Freedman LP. Signaling by estrogens. J Cell Physiol. 2007;213(3):610-617.

45. Huang B, Qu Z, Ong CW, et al. RUNX3 acts as a tumor suppressor in breast cancer by targeting estrogen receptor alpha. Oncogene. 2012;31(4): $527-534$.

46. Wang X, Zheng X, Lin X, Shi Y, He Y, Chen G. [Methylation of Runx3 promoter in different breast lesions]. Zhonghua Bing Li Xue Za Zhi. 2014;43(7):447-450. Chinese.

47. Dongxia Li HW, Jianzhi Gao, Zhixin Fang. Relationship between methylation status of Runx3 gene promoter and Runx3 protein expression in patients with breast cancer. China Maternal and Child Health. 2013;22.

48. Park SY, Kwon HJ, Choi Y, et al. Distinct patterns of promoter CpG island methylation of breast cancer subtypes are associated with stem cell phenotypes. Mod Pathol. 2012;25(2):185-196.

49. Li Qiao ZY, Wei Liu. Clinical Significance of Detecting Plasma Runx3 Gene Promotor Methylation in Early Diagnosis Breast Cancer. Modern Laboratory Medicine. 2012;27.

50. Park SY, Kwon HJ, Lee HE, et al. Promoter CpG island hypermethylation during breast cancer progression. Virchows Arch. 2011;458(1) 73-84.

51. Subramaniam MM, Chan JY, Omar MF, et al. Lack of RUNX3 inactivation in columnar cell lesions of breast. Histopathology. 2010;57(4) 555-563.

52. Jin-rong Du GL, Ying Jiang. Relationship between the methylation of RUNX3 promoter and the clinical pathological characters and prognostic factors of breast invasive ductal carcinoma. Journal of Harbin Medical University. 2008;1.

53. Shengwang Tian SJ, Jian Chen. Analysis of the status of Runx3 gene promoter methylation in breast cancer and its relationship with pathological features. Chinese Journal of Breast Disease. 2010;4.

54. Yan Z, Gao S, Wu X, Liu H. [Correlation between the methylation status of Runx3 gene and positive expression of estrogen receptor in breast cancer]. Zhonghua Bing Li Xue Za Zhi. 2015;44(4):240-244. Chinese.
OncoTargets and Therapy

\section{Publish your work in this journal}

OncoTargets and Therapy is an international, peer-reviewed, open access journal focusing on the pathological basis of all cancers, potential targets for therapy and treatment protocols employed to improve the management of cancer patients. The journal also focuses on the impact of management programs and new therapeutic agents and protocols on

\section{Dovepress}

patient perspectives such as quality of life, adherence and satisfaction. The manuscript management system is completely online and includes a very quick and fair peer-review system, which is all easy to use. Visit http://www.dovepress.com/testimonials.php to read real quotes from published authors. 